Jurnal Abdimas Berdaya : Jurnal Pembelajaran, Pemberdayaan dan Pengabdian Masyarakat Volume 4 Nomor 02 Tahun 2021

\title{
Pelatihan Pembuatan Payung Solar Cell
}

\section{Solar Cell Umbrella Making Training}

\author{
Sulistiyanto $^{1)}$, Ach Najihuddin $^{2)}$, Adi Riyanto $^{3)}$, Taufiq Hidayatullah ${ }^{4)}$, Moh Basri ${ }^{5)}$ \\ 1,2,3,4,5 Universitas Nurul Jadid \\ e-mail: ${ }^{1}$ sulistiyanto@ymail.com, ${ }^{2}$ achnajihuddin6@ gmail.com, \\ ${ }^{3}$ adirynto22@gmail.com, ${ }^{4}$ taufiq02201@gmail.com, ${ }^{5}$ masboy06088@gmail.com
}

\begin{abstract}
Abstrak: Ketrampilan instalasi Solar panel/ solar cell sangat dibutuhkan untuk saat ini, tidak terkeuai bagi para santri. Hal ini karena cadangan bahan bakar minyak sudah mulai menipis, dan pemerintah serta trend dunia sudah mengarah ke pada kebutuhan Energi Baru dan terbarukan. Santri Nurul Jadid sebagai pesantren yang besar di wilayah Probolinggo sudah memiliki Balai Latian Kerja (BLK) untuk membekali para santri ketika sudah selesai mondok. Dengan adanya Prodi Elektro di Universitas Nurul Jadid maka perlu memberikan transfer teknologi bagi para santri dalam bentuk pengabdian masyarakat,. Pengabdian itu berbentuk instalasi PLTS berbentuk Meja Payung Solar Cell.
\end{abstract}

Kata Kunci: Meja, Payung, Solar Cell, Instalasi

Abstract: Solar panel/solar cell installation skills are needed at this time, not to mention the students. This is because fuel oil reserves have started to run low, and the government and world trends have turned to the need for new and renewable energy. Santri Nurul Jadid as a large Islamic boarding school in the Probolinggo area already has a Work Training Center (BLK) to equip the students when they have finished boarding. With the Electrical Engineering Study Program at Nurul Jadid University, it is necessary to provide technology transfer for students in the form of community service. The service is in the form of a PLTS installation in the form of a Solar Cell Umbrella Table.

Keywords: Table, Umbrella, Solar Cell, Installation

\section{A. Pendahuluan}

Pondok pesantren Nurul Jadid berada di Desa Tanjung, merupakan desa yang terletak di Kecamatan Paiton Kabupaten Probolinggo. Di wilayah Kabupaten Probolinggo ada 285 Pondok pesantren yang tersebar di beberapa kecamatan. Pondok pesantren sendiri merupakan sebuah lembaga pendidikan Islam dimana para santrinya biasanya menetap dalam asrama (pondok). Kecamatan Paiton Kabupaten Probolinggo terdapat 23 Pondok Pesantren, diantaranya yaitu Pondok pesantren Nurul Jadid yang merupakan Pondok terbesar di Kecamatan Paiton. (https://sippa.ciptakarya.pu.go.id/)

Saat ini pesantren Nurul Jadid memiliki 7025 Santri yang bermukim di pondok pesantren. Lembaga pendidikan yang ada di Pondok Nurul Jadid diantaranya, PAUD, MI, MTs, MA, SMA, SMK dan Universitas. Lembaga pendidikan tersebut tidak hanya membekali para santri di bidang akademik, tetapi ketrampilan dan wirausaha. Untuk 
wirausaha pondok pesatren memiliki koperasi, dan minimarket dengan nama NJmart, perkebunan tembakau, toko elektronik, toko bangunan.

Di Pondok pesantren ada lembaga pendidikan yang mengatur semua kegiatan pendidikan mulai dari TK, MI, MTs, MA, SMP dan SMA. Selain lembaga pendidikan juga ada lembaga pelatian ketrampilan softskill yang ditangani oleh Balai Latian Kerja (BLK). Untuk BLK selama ini belum ada kegiatan pelatihan peningkatan ketrampilan kkelistrikan solar panel, pada saat ini Enenrgi Baru Terbarukan (EBT) sedang viral, maka perlu diadakan pelatian instalasi Listrik Tenaga Solar Cell bagi santri di Pondok Nurul Jadid. Lokasi Pondok pesatren Nurul Jadid sangat banyak mendapat sinar matahari, gedung-gedung atau rumah disekitar pondok tidak terlalu tinggi, sehingga sangat cocok bila menggunakan Pembangkit Listrik Tenaga Surya. Selama ini Pondok pesantren tidak memanfaatkan teknologi ini dikarenakan sumberdaya manusia yang ada belum mengerti dan memahami instalasi Pembangkit Listrik Tenaga Surya (PLTS) untuk kebutuhan sehari hari. Bila pengetahuan PLTS ini sudah dipahami dan menjadi ketrampilan bagi santri maka lulusan pesantren Nurul Jadid akan punya nilai lebih, yaitu di bidang instalasi tenaga listrik dengan menggunakan tenaga surya (PLTS).

\section{Permasalahan Mitra}

Hasil pendekatan dan survey dengan ke Mitra, sebagai pondok pesantren yang besar sudah tentu membutuhkan sumber daya listrik yang besar juga. Disatu sisi pondok pesantren juga memiliki kegiatan social jadi bila biaya listrik yang dikeluarkan cukup besar juga menjadi permasalahan dalam pengelolaan keuangan (1). Perlunya ketrampilan santri untuk instalasi PLTS. (2). Perlu adanya modul instalasi Solar Panel yang tepat guna agar pada santri bias pepmbuat produk tersebut di masyarakat.

Jadi sudah seharusnya pondok pesantren Nurul Jadid menggunakan sumber energi lain, dari kondisi alam dan lingkungan seperti di analisis situasi yang merupakan daerah datar yang luas dan tidak ada bangunan tinggi yang tepat adalah menggunakan teknologi PLTS.

\section{B. Metode}

Dari kedua permasalahan tersebut bisa dijadikan 2 kegiatan yaitu :

1. Pembuatan Meja Payung dari besi yang diatasnya dilengkapi solar panel lengkap dengan komponen PLTS sehingga bisa menghasilkan listrik.

2. Hasil produk pelatihan bisa di kembangkan dan diproduksi oleh para santri pondok pesantren. 


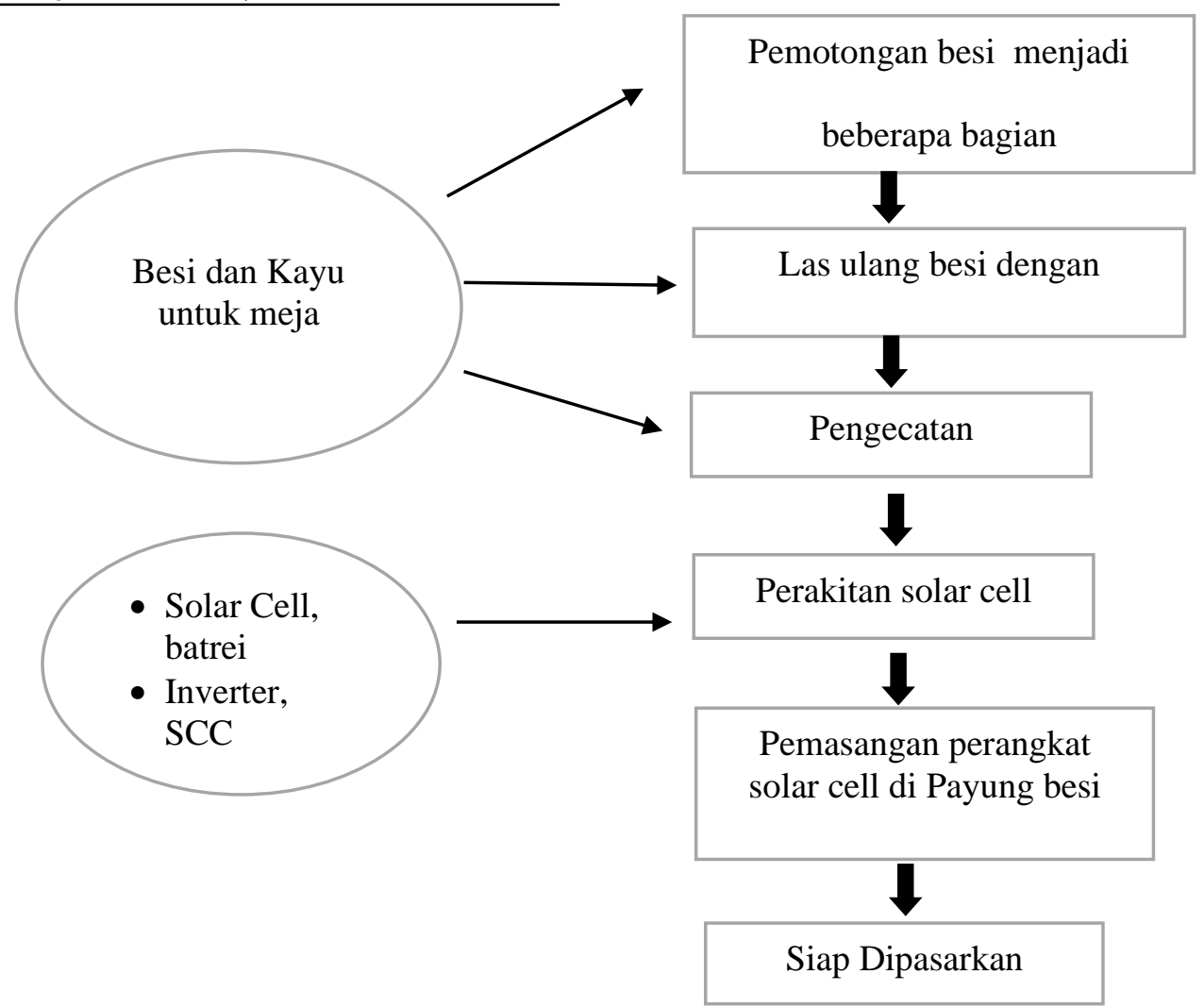

Gambar 1. Skema proses pembuatan

Pembangkit listrik tenaga surya sangat ramah lingkungan, dan sangat melimpah di daerah paiton khususnya dekat pesantren Nurul Jadid. PLTS ini sebagai salah satu alternative untuk menggantikan listrik dari PLN karena selama ini biaya listrik yang harus dibayar pondok cukup besar, dan menjadi beban pondok pesantren. Metode pendekatan yang ditawarkan kepada Pondok pesantren Nurul Jadid dengan membuatkan meja payung dari besi yang bertenaga surya, yang mana nanti tempat panel suryanya diletakkan di atas payung, agar nanti para santri pondok pesantren bisa melakukan pelatihan penerapan ilmu dan teknologi dalam pembuatan solar cell. Disini akan dikenalkan komponen-komponen dan alat pembuatan panel surya, serta bagaimana cara merakit panel surya yang dihubungkan dengan komponenkomponen lainnya serta penggunaanya ketika dipakai sampai menghasilkan energi listrik. Prosedur kerja untuk mendukung metode tersebut adalah panel surya yang digunakan kemudian dirakit menjadi satu agar menghasilkan daya watt sesuai dengan yang di inginkan. Setiap sel surya disusun secara seri untuk mendapatkan output tegangan yang maksimal. Dalam aplikasinya nanti Meja payung solar cell, membutuhkan 1 lembar panel surya 50wp untuk menekan biaya agar lebih murah, tetapi bias dikembangkan bila mau menjadi 100wp, cukup dengan memasang seri panel surya yang ada.

Output dari panel surya adalah arus searah (DC) yang nantinya akan diubah menjadi arus bolak-balik (AC) untuk keperluan lampu dan stok kontak di Meja 
Payung solar cell, serta peralatan listrik lainya. (Qomaruddin, 2019). Merangkai suatu panel surya untuk PLTS memerlukan beberapa perangkat tambahan berikut:

1. Solar charge controller

2. Baterai atau accumulator

3. Inverter DC/AC

\section{Hasil dan Pembahasan}

Dalam pelatihan ini menggunakan alat Meja Payung yang sudah ada, dengan komponen elekronik yang dibunakan 1 buah solar panel 50wp, solar charger controller, inverter dan batrei ukuran 7,5Ah. Sebelum dilakukan pelatian peserta dikenalkan terlebih dahulu teori bagaimana instalasi perangkat elektronik dalam pembuatan Pembangkit Listrik Tenaga Surya (PLTS).

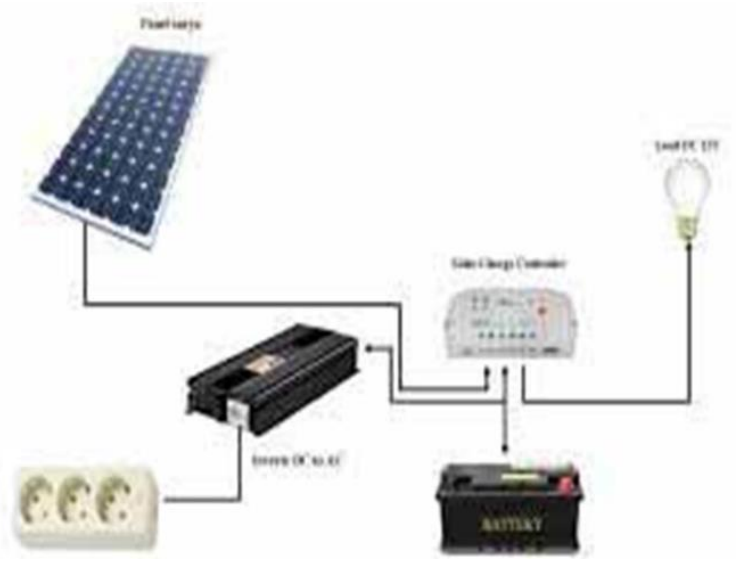

Gambar 2. Rangkaian Instalasi Meja Payung Solar Cell

Setelah materi instalasi selesai di lanjutkan dengan teori perhitungan beban. Pada pemakaianya nanti beban dibatasi maksimum 50 whatt alat elektronik portabel dengan spesifikasi pengisian $5 \mathrm{~V}-1 \mathrm{~A}$ per unitnya, jadi dapat dihitung:

$$
\begin{aligned}
& \mathrm{V}=5 \mathrm{~V}, \mathrm{I}=1 \mathrm{~A} \\
& \mathrm{P}=\mathrm{V} \times \mathrm{I}=5 \times 1 \\
& \mathrm{P}=5 \mathrm{w} \times 10=50 \text { watt per jam }
\end{aligned}
$$

Perhitungan Modul Solar Cell

Diketahui kapasitas baterai adalah 288watt per jam, dengan asumsi paparan sinar matahari efektif yang di dapat adalah selama 4 jam maka. Diasumsikan memakai modul solar cell berjumlah $50 \mathrm{watt}$ atau $5 \mathrm{~V}-10 \mathrm{~A}$

$$
\begin{aligned}
& \mathrm{E}=50 \text { watt } \\
& \mathrm{T}=4 \text { jam } \\
& \mathrm{P}=4 \times 50=200 \text { Watt }
\end{aligned}
$$


Pengisian daya baterai pada Meja Payung Solar Cell ini sekitar 288 watt per jam dengan daya 50 watt per jam di dapatkan:

$288 / 50=5,76$ yaitu sekitar 6 jam 16 menit.

Karena voltase dari panel surya bervariasi, maka diperlukan pengatur voltase supaya bisa dipakai untuk mengisi baterai yang telah dirakit parallel, di sini digunakan Auto Buck Bosst DC Converter sebagai pengganti controllerpanel surya yang umummnya beroperasi di 12v. (Haryadi, 2017).

\section{Design}

Untuk design kerangka besi dari meja payung JAYUS bisa di lihat seperti pada Gambar 3, kerangka ini sengaja di buat design yang mudah di bongkar pasang, agar pengguna dapat mebawah meja payung ini dengan mudah, Atap payung, meja, tiang dan alas kaki dari payung bisa di lepas: (Damara, 2021)

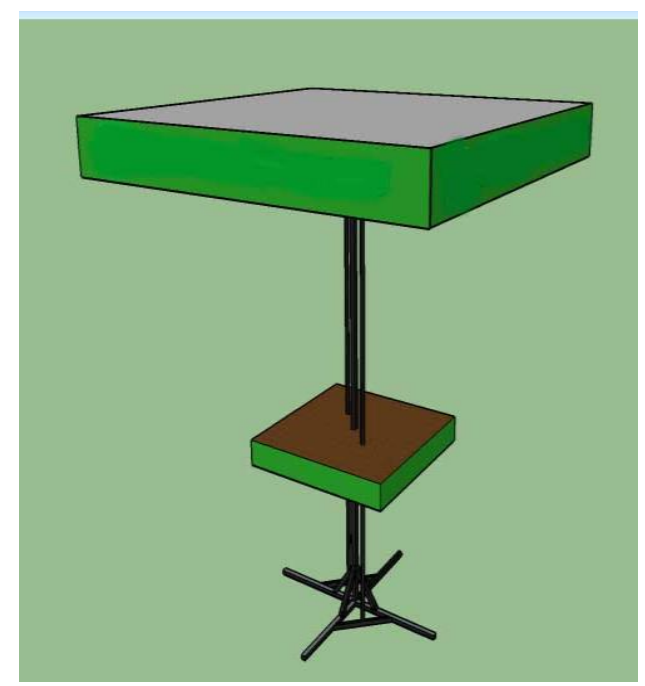

Gambar 3. Design Meja Payung Solar Cell 


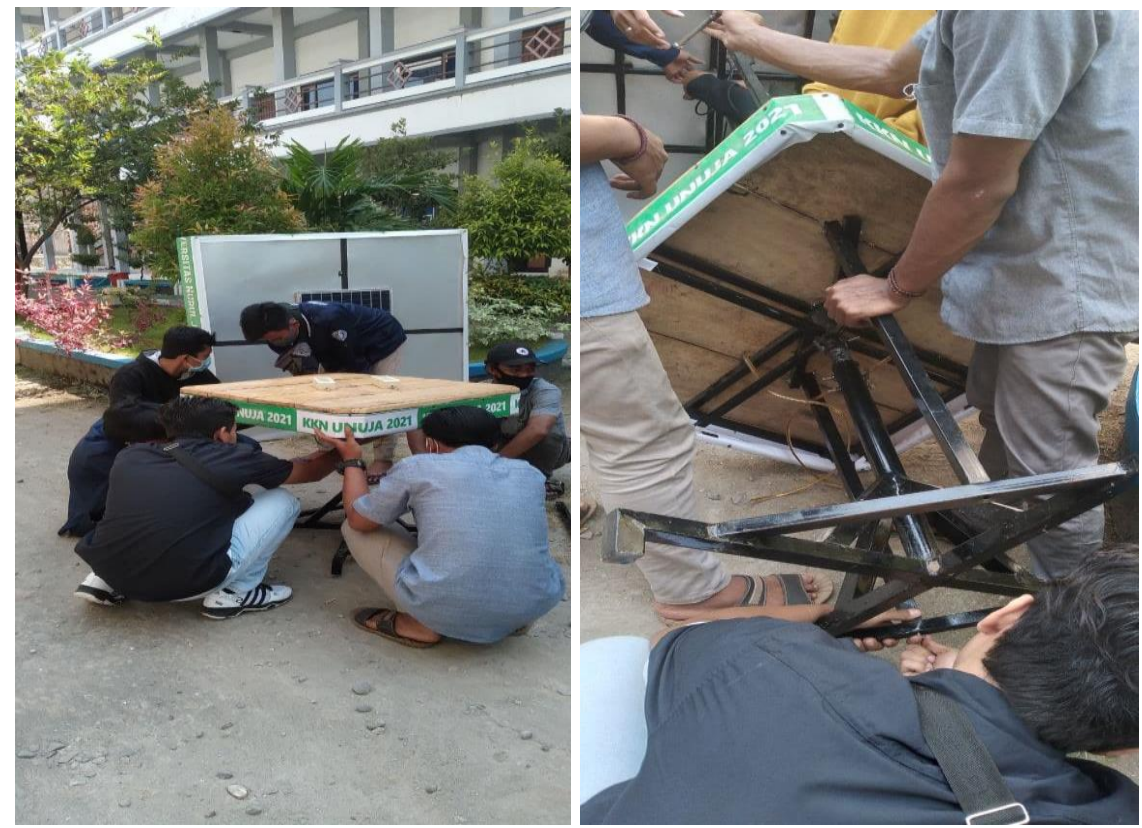

Gambar 4. Perakitan Meja Payung

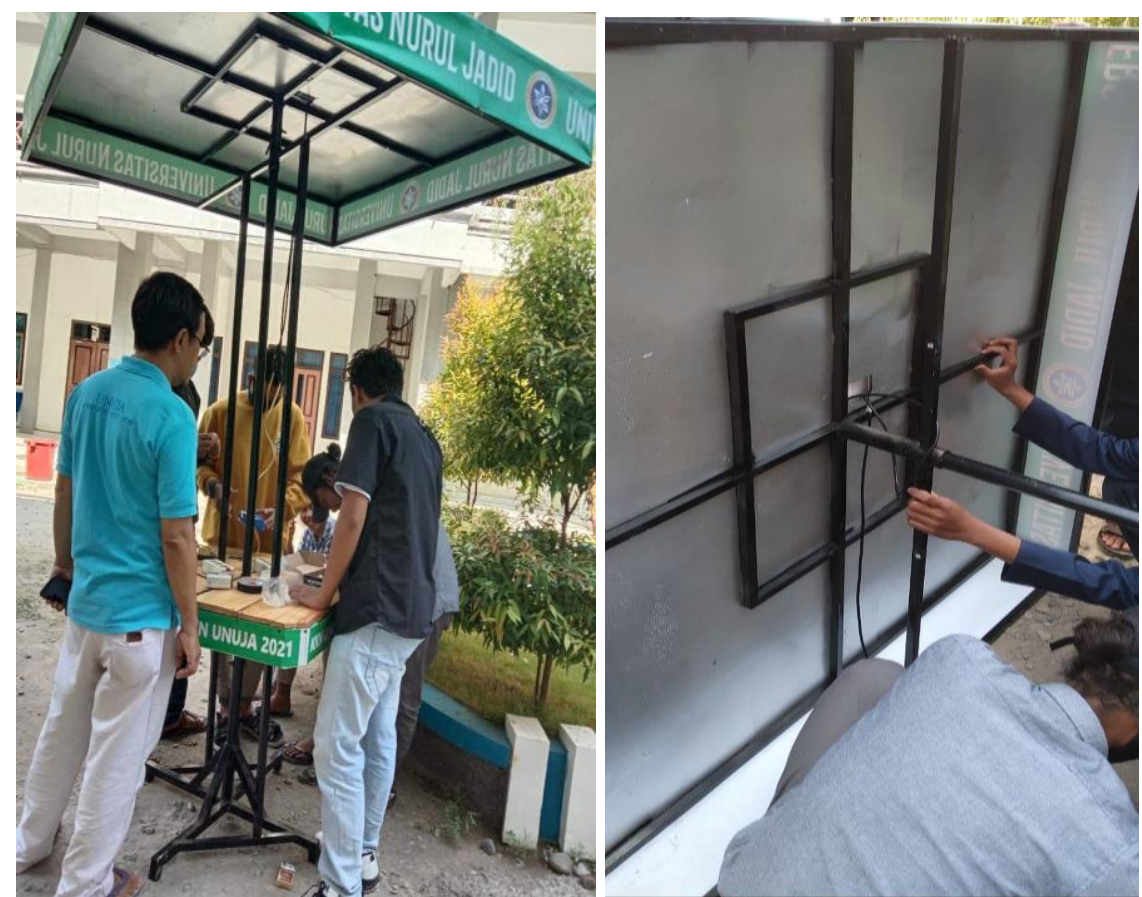

Gambar 5. Instalasi Komponen Solar Cell, SCC dan lampu

Pelatihan instalasi yang dilakukan mulai dari pemasangan meja payung dan pemasangan instalasi solar cell yang terdiri dari komponen yang digunakan dalam meja payung solar cell. Para santri sangat antusias dalam mengikuti pelatihan tersebut, karena bagi mereka ini merupakan pengetahuan baru dan tidak perlu jauh jauh belajar keluar 
pondok, tetapi cukup di dalam pondok, dengan dipandu oleh dosen dan mahasiswa Prodi Teknik Elektro Universitas Nurul Jadid.

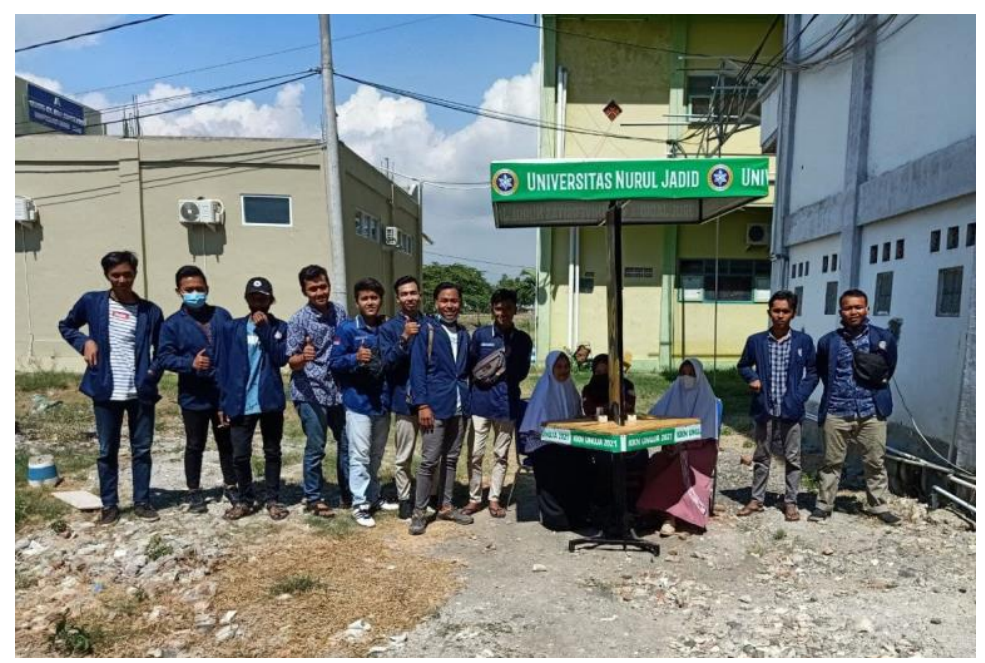

Gambar 6. Foto bersama kelompok pengabdian

\section{Simpulan}

Berdasarkan hasil dari kegiatan pelatihan pembuatan payung solar cell dapat disimpulkan bahwa

1. Pelatihan instalasi meja payung solar cell bagi santri ini berdampak pada peningkatan pengetahuan dan ketrampilan santri pondok pesantren Nurul Jadid dalam membuat PLTS sederhana.

2. Ketrampilan perakitan dan instalasi PLTS dalam bentuk meja payung solar cell ini bisa menjadi ketrampilan tambahan santri, dan para santri bisa mengebangkan instalasi PLTS itu untuk pembuatan Gazebo solar cell di pondok Nurul Jadid. 
(Sulistiyanto, dkk)

\section{Daftar Rujukan}

Damara, T. P. A., Mustaqim, A., Devyce, A., \& Adawiyah, R. (2021). "JAYUS” Meja Payung Solar Cell. Jurnal Teknik Elektro dan Komputer TRIAC, 8(1), 23-25.

Dinas PUPR Probolinggo, (2018), Rencana Pembangunan Jangka Menengah Daerah, https://sippa.ciptakarya.pu.go.id/sippa_online/ws_file/dokumen/rpi2jm/DOCRPIJ M_4bf3f8e555_BAB\%20II2.\%20BAB\%20II_Review\%20RPJMD.pdf

Haryadi, S., \& Syahrillah, G. R. F. (2017). Rancang Bangun Pemanfaatan Panel Surya Sebagai Charger Handphone Di Tempat Umum. AL-JAZARI JURNAL ILMIAH TEKNIK MESIN, 2(1).

Qomaruddin, M. N., \& Khairi, M. (2019). Real Time Clock Sebagai Tracking Sinar Matahari Pada Solar Cell Berbasis Mikrokontroler Untuk Lampu Tama. Jurnal Qua Teknika, 9(2), 27-32.

Yudhy Wiranatha Jaya Kusuma, Noer Soedjarwanto, 2015. Rancang Bangun Penggerak Otomatis Panel Surya Menggunakan Sensor Photodioda Berbasis Mikrokontroller ATMEGA 16, jurnal rekayasa dan Teknik Elektro Vol.9 